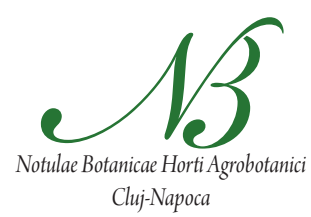

\title{
Biological and Chemical Phosphorus Fertilizers Effect on Yield and P Accumulation in Rapeseed (Brassica napus L.)
}

\author{
Hamid MADANI ${ }^{1 *}$, Mohammad Ali MALBOOBI², Kioomars \\ BAKHSHKELARESTAGHI ${ }^{3}$, Agnieszka STOKLOSA ${ }^{4}$ \\ ${ }^{1}$ Islamic Azad University, Arak Branch, Department of Agronomy, Arak, Iran; h-madani@iau-arak.ac.ir ('corresponding author) \\ ${ }^{2}$ National Institute for Genetic Engineering and Biotechnology (NIGEB), Tehran, Iran \\ ${ }^{3}$ Islamic Azad University, Mashhad, Department of Agronomy, Mashhad Branch, Iran \\ ${ }^{4}$ University of Agriculture, Department of Agrotechnology and Agricultural Ecology, Krakow, Poland
}

\begin{abstract}
A field experiment was conducted to investigate different phosphorus fertilizer sources and their importance in rapeseed farms on 2007 at Arak, Iran. Ammonium phosphate fertilizer with 50\% $\mathrm{P}_{2} \mathrm{O}_{5}$ (APF) was used as a chemical phosphorus source with 3 rates of application, whereas phosphorus solubilizing bacteria (PSB) was a biological source of phosphorus used in 4 rates. Experiment was a factorial arrangement in complete randomized block design with 3 replications. APF levels were: control (AP0), 125 kg/ha APF (AP1) and $250 \mathrm{~kg} / \mathrm{ha}$ (AP2) application and PSB levels were: control (PSB0), PSB at sowing time only (PSB1), PSB as top dress fertilizer after over wintering only (PSB2) and PSB at dual fertilizing in sowing time and also after over wintering (PSB3). The statistical analyses showed that the PSB3 treatment was the best treatment for the seed yield increase. The highest rate of seed yield ( $9.9 \mathrm{t} / \mathrm{ha})$ was recorded in dual fertilizing applied both, in sowing time and after over wintering stage of rosette. The interaction effects of phosphorus solubilizing bacteria and ammonium phosphate fertilizer application had not significant effect on plant height, biomass yield, number of silique per plant, seed oil percent and seed yield. Interaction effects of phosphorus solubilizing bacteria and ammonium phosphate fertilizer application were significant for phosphorus content in plant tissues.
\end{abstract}

Keywords: ammonium phosphate fertilizer, phosphorus solublizing bacteria, rapeseed, yield

\section{Introduction}

The role of phosphorus in plant growth have been investigated by many teams (Antoun et al, 1996; Hinsinger, 2001; Nikolay et al., 1996; Pant and Reddy, 2003, Shafeek et al., 2004; Warade et al., 1996). All of them agree, that the presence of phosphorus $(\mathrm{P})$ in the soil encourages plant growth, because phosphorus is an essential nutrient. Currently, lack of this element would be repaired by the use of biological manure and/or chemical P fertilizers. The last ones might have harmful effects on the environment and on the quality of agricultural products. There is no doubt that mineral fertilizers are essential in most of cropping systems if maximum yields are to be realized (Barraclough, 1989). However, in long-term field experiments where mineral fertilizers have only been used, soil structure has deteriorated and crop yield steadily decreased as reviewed by Ristimaki et al. (2000).

However, the availability of soil $P$ to the plant depends largely on the quantity of sources stored in the soil, influencing negative or the positive results (Goldstein, 1986). Therefore, inorganic phosphorus is readily absorbed and used by plant if it is not fixed. Nikolay et al. (1996) reported, that organic phosphorus is mineralized and immobilized by microbes' activities. Mineralization is the conver- sion of organic phosphorus into inorganic phosphorus, while, the immobilization of phosphorus involves the formation of organic phosphorus from its inorganic forms. The availability of phosphorus can be also improved by applying bacteria, in the form of biological fertilizers, to form inoculates and improve nutrients availability (Chen et al., 2006; Kloepper et al., 1989; Nautiyal, 2000). The paper aims at a comparison of two forms of phosphorus fertilizers: biological phosphorus (phosphorus solubilizing bacteria) as a biological fertilizer and ammonium phosphate as a chemical fertilizer and to investigate their effect on the growth, seed yield and some physiological properties of rapeseed.

\section{Materials and methods}

To study biological and chemical phosphorus fertilizers effect on yield and phospohorus accumulation in irrigated rapeseed (Brassica napus L.) a field experiment was conducted during September 2006 to October 2007 at Arak Islamic Azad University research fields, Arak, Iran. The physical and chemical properties of soil are presented in Tab. 1. Ammonium phosphate fertilizer with $50 \% \mathrm{P}_{2} \mathrm{O}_{5}$ (APF) was the chemical phosphorus source with three rates of application and phosphorus solubilizing bacteria 
(PSB) was the biological phosphorus source used in four levels. There were 12 different combinations of fertilizer and its dose in the experiment. Two different treatments were arranged in a randomized complete block design (RCBD) with 3 replications. Rapeseed cultivar 'Okapi' (B. napus) was used in the trial.

APF Treatments had three rates which included control (AP0), $125 \mathrm{~kg} / \mathrm{ha}$ APF (AP1) and $250 \mathrm{~kg} / \mathrm{ha}$ (AP2), equal to local recommended dose of $\mathrm{P}$ fertilizer applied to soil on first of September. PSB treatment (a combination Pantoea agglomerans strains P5 and Pseudomonas putida strain P13) had four levels, control without PSB (PSB0), consumption of $100^{*} 10^{8}$ CFU PSB per $100 \mathrm{~g}$ bio-fertilizer at sowing time only (PSB1), consumption of $100^{*} 10^{8} \mathrm{CFU}$ PSB per $100 \mathrm{~g}$ bio-fertilizer as top dress fertilizer after over wintering only (PSB2) and consumption of $100^{*} 10^{8} \mathrm{CFU}$ PSB per $100 \mathrm{~g}$ bio-fertilizer as dual fertilizing at sowing time and also after over wintering (PSB3) as PSB soluble in 400 litter of water/ha and add manually in soil.

Tab. 1. Physical and chemical analysis of soil of the experimental field

\begin{tabular}{|c|c|}
\hline Physical properties & $0-30$ depth $(\mathrm{cm})$ \\
\hline Soil texture & Sandy loam \\
\hline Clay $(\%)$ & 12 \\
\hline Silt (\%) & 36 \\
\hline Fine send $(\%)$ & 52 \\
\hline \multicolumn{2}{|c|}{ Chemical analysis } \\
\hline Available (K) (mg/1000 g soil) & 434 \\
\hline Available (P) (mg/1000 g soil) & 11.4 \\
\hline Total nitrogen (mg/1000 g soil) & 6.2 \\
\hline $\mathrm{Cl}(\mathrm{meq} / \mathrm{L})$ & - \\
\hline $\mathrm{CaCO} 3(\%)$ & 28 \\
\hline Organic matter (\%) & 0.61 \\
\hline SO 4 (ppm) & - \\
\hline $\mathrm{EC}\left(\mathrm{ds} / \mathrm{m} / 25^{\circ} \mathrm{C}\right)$ & 0.6 \\
\hline $\mathrm{pH}$ & 8.0 \\
\hline
\end{tabular}

Planting dates was on September 5' in 2007, Rapeseed seeds were sown manually in rows, $8 \mathrm{~m}$ long, $30 \mathrm{~cm}$ apart and the distance between ridges was $30 \mathrm{~cm}$. The typical cultural practices for the rapeseed production, i.e. application of other fertilizers, irrigation, weed and pest management were applied. Plant height was recorded on 5 plants per plot which were taken randomly from every experimental plot.

At harvest time on 20 June 2007, the final yield biomass, number of silique per plant, the content of oil in grain and grain yield were calculated from $4 \mathrm{~m}^{2}$, when the plant water content was less than $10 \%$. Phosphorus content in vegetative (before flowering) stage and reproductive plant parts (before seed formation) and mature seed (seeds with 10-12\% humidity) was measured according to the method described by Troug and Mayer (1939). The obtained data were subjected to the analysis variance pro- cedure and treatment means were compared to the Duncan multiple test, using MSTAT-C software.

\section{Results and discussion}

\section{Ammonium phosphate fertilizer (APF) effects}

Response of rapeseed to phosphorus application showed significant changes in the phosphorus content in vegetative and reproductive plant parts (Tab. 2). The phosphorus content in seeds was also changed by ammonium phosphate fertilizer amounts of $11.4 \mathrm{mg} \mathrm{P}_{2} \mathrm{O}_{5}$ per $100 \mathrm{~g}$ of soil. Increase in ammonium phosphate fertilizer application from 125 to $250 \mathrm{~kg} / \mathrm{ha}$ could increase the seed yields from 5.16 to $6.11 \mathrm{t}$ /ha (Fig. 1, I). However, ammonium phosphate fertilizer treatments could not deposit significant differences on plant height, biomass yield, number of silique per plant and oil seed content.

Study of APF simple effects on rapeseed grain yield showed that the highest seed yield of $6.11 \mathrm{t} / \mathrm{ha}$ was obtained when $250 \mathrm{~kg} / \mathrm{ha}$ ammonium phosphate fertilizer (AP2) in sowing time was used. The lowest yield of 3.43 t/ha was observed in control plots. In other words, grain yield was significantly higher at all APF levels used (Tab. 1 I). However, mean comparison table shows that grain yield increased significantly by rising consumption of APF from 0 to $250 \mathrm{~kg} / \mathrm{ha}$. Similar result has been reported by Pant and Reddy (2003).

\section{Effects of Phosphorus Solubilizing Bacteria (PSB)}

Rapeseed growth and development response to phosphorus solubilizing bacteria (PSB) was significant for plant height, biomass yield, number of silique per plant and grain yield (Tab. 2).

The phosphorus solubilizing bacteria application in all levels and comparing to control increased the plant height from 77.7 to $97.3 \mathrm{~cm}$. PSB as a top dress fertilizer applied after over wintering was the main cause of increasing the plant height from $77.7 \mathrm{~cm}$ to $92.6 \mathrm{~cm}$. The highest plants $(97.3 \mathrm{~cm})$ were recorded when the PSB fertilizer was applied twice at sowing date and after over wintering stage (Fig. 2, I).

The rapeseeds that had been treated by PSB show significant increase in biomass yield from 7.5 to $11.4 \mathrm{t} / \mathrm{ha}$ (Fig. 2, II). Therefore, biomass yield was one of the most susceptible determinative to PSB application. The number of silique per plant was 115.8 in case of PSB3 application rate.

Phosphorus availability in soil would be successful in amplifying the number of silique per plant. We recorded number of silique per plant from 62.0 in control ( $\mathrm{P}$ was $11.4 \mathrm{ppm}$ ) to 115.0 silique per plant when soil was treated by PSB3. Thus, the comparison of number of silique per plant showed $44 \%$ increase when PSB fertilizer was used, as compared to control (Fig. 2, III).

PSB consumption also could increase the grain yield significantly (Tab. 2). The highest effect of PSB on grain yield was showed for dual fertilizing in sowing time and after rosette over wintering ( $9.9 \mathrm{t} / \mathrm{ha})$ and the lowest one 
212

Tab. 2. Effect of different sources and rates of phosphorus fertilizer application on growth characters of rapeseed

\begin{tabular}{|c|c|c|c|c|c|c|c|c|}
\hline \multirow[t]{2}{*}{ Treatments } & $\begin{array}{l}\text { Plant } \\
\text { height }\end{array}$ & $\begin{array}{c}\text { Biomass } \\
\text { yield }\end{array}$ & $\begin{array}{l}\text { No. silique } \\
\text { per plant }\end{array}$ & $\begin{array}{l}\text { Oil seed } \\
\text { content }\end{array}$ & $\begin{array}{l}\text { Grain } \\
\text { yield }\end{array}$ & $\begin{array}{l}\text { P content } \\
\text { vegetative } \\
\text { plant part }\end{array}$ & $\begin{array}{l}\text { P content } \\
\text { reproductive } \\
\text { plant parts }\end{array}$ & $\begin{array}{l}\text { Grain P } \\
\text { content }\end{array}$ \\
\hline & $(\mathrm{cm})$ & t/ha & No. & $\%$ & $\mathrm{~kg} / \mathrm{ha}$ & $\%$ & $\%$ & $\%$ \\
\hline APF0 & 91.11 & 9.38 & 61.58 & 48.93 & $3.43 c$ & $0.19 \mathrm{c}$ & $0.53 c$ & $0.51 \mathrm{c}$ \\
\hline APF1 & 85.90 & 8.96 & 76.88 & 49.07 & $5.16 \mathrm{~b}$ & $0.22 b$ & $0.55 \mathrm{ab}$ & $0.61 \mathrm{~b}$ \\
\hline APF2 & 87.61 & 10.60 & 98.50 & 49.05 & $6.11 \mathrm{a}$ & $0.29 \mathrm{a}$ & $0.57 \mathrm{a}$ & $0.69 \mathrm{a}$ \\
\hline \multicolumn{9}{|l|}{ Mean } \\
\hline PSB0 & $77.70 \mathrm{c}$ & $7.45 \mathrm{~b}$ & $62.29 \mathrm{c}$ & 48.36 & $3.02 \mathrm{~d}$ & $0.21 \mathrm{c}$ & $0.51 \mathrm{c}$ & $0.53 \mathrm{c}$ \\
\hline PSB1 & $85.22 \mathrm{~b}$ & $10.00 \mathrm{ab}$ & $82.38 b c$ & 49.04 & $4.99 c$ & $0.26 b$ & $0.58 \mathrm{~b}$ & $0.63 \mathrm{~b}$ \\
\hline PSB2 & $92.57 \mathrm{a}$ & $9.74 \mathrm{ab}$ & $95.48 \mathrm{~b}$ & 49.16 & $7.03 b$ & $0.32 \mathrm{a}$ & $0.63 \mathrm{ab}$ & $0.68 \mathrm{a}$ \\
\hline PSB3 & $97.33 \mathrm{a}$ & $11.40 \mathrm{a}$ & $115.79 \mathrm{a}$ & 49.51 & $9.90 \mathrm{a}$ & $0.33 \mathrm{a}$ & $0.69 \mathrm{a}$ & $0.68 \mathrm{a}$ \\
\hline \multicolumn{9}{|l|}{ Mean } \\
\hline APF0 PSB0 & 83.00 & 7.15 & 55.08 & 48.08 & 2.60 & $0.21 \mathrm{e}$ & $0.52 \mathrm{e}$ & $0.54 \mathrm{~d}$ \\
\hline APF0 PSB1 & 85.43 & 10.12 & 84.43 & 49.07 & 5.15 & $0.23 \mathrm{~d}$ & $0.55 \mathrm{~d}$ & $0.61 \mathrm{c}$ \\
\hline APF0 PSB2 & 97.23 & 9.61 & 102.56 & 49.23 & 7.21 & $0.25 c$ & $0.62 b c$ & $0.66 \mathrm{ab}$ \\
\hline APF0 PSB3 & 98.77 & 10.66 & 124.26 & 49.33 & 10.77 & $0.22 \mathrm{~d}$ & $0.68 b$ & $0.66 \mathrm{ab}$ \\
\hline APF1 PSB0 & 73.67 & 7.80 & 51.92 & 48.20 & 2.83 & $0.25 c$ & $0.55 \mathrm{~d}$ & $0.60 \mathrm{c}$ \\
\hline APF1 PSB1 & 84.80 & 9.52 & 70.74 & 49.48 & 4.70 & $0.31 b$ & $0.58 \mathrm{c}$ & $0.65 b c$ \\
\hline APF1 PSB2 & 89.90 & 8.33 & 92.08 & 49.07 & 7.32 & $0.33 \mathrm{ab}$ & $0.63 \mathrm{bc}$ & $0.66 \mathrm{ab}$ \\
\hline APF1 PSB3 & 95.23 & 10.18 & 92.76 & 49.54 & 9.77 & $0.35 a$ & $0.69 \mathrm{~b}$ & $0.66 \mathrm{ab}$ \\
\hline APF2 PSB0 & 76.43 & 7.40 & 79.87 & 48.79 & 3.63 & $0.23 \mathrm{~d}$ & $0.70 \mathrm{~b}$ & $0.62 \mathrm{c}$ \\
\hline APF2 PSB1 & 85.43 & 10.36 & 91.98 & 48.56 & 5.12 & $0.28 b c$ & $0.73 \mathrm{ab}$ & $0.66 \mathrm{ab}$ \\
\hline APF2 PSB2 & 90.57 & 11.27 & 91.81 & 49.17 & 6.55 & $0.31 \mathrm{~b}$ & $0.78 \mathrm{a}$ & $0.69 \mathrm{a}$ \\
\hline APF2 PSB3 & 98.00 & 13.36 & 130.33 & 49.67 & 9.15 & $0.36 \mathrm{a}$ & $0.78 \mathrm{a}$ & $0.68 \mathrm{a}$ \\
\hline \multicolumn{9}{|c|}{ Mean square probability } \\
\hline APF & ns & ns & 0.03 & $\mathrm{~ns}$ & 0.02 & 0.014 & 0.33 & 0.10 \\
\hline PSB & 0.005 & 0.006 & 0.004 & 0.2 & 0.002 & 0.036 & 0.02 & 0.02 \\
\hline APF. PSB & $\mathrm{ns}$ & $\mathrm{ns}$ & $\mathrm{ns}$ & $\mathrm{ns}$ & $\mathrm{ns}$ & 0.005 & 0.01 & 0.01 \\
\hline CV\% & 9.92 & 19.51 & 20.32 & 1.68 & 13.64 & 2.02 & 3.12 & 3.62 \\
\hline
\end{tabular}

Means with the same letters are not significantly different at $p(<0.05)$. AP=ammonium phosphate; $\mathrm{AP} 0=\mathrm{Control} ; \mathrm{AP1}=125 \mathrm{~kg} / \mathrm{ha} ; \mathrm{AP} 2=250 \mathrm{~kg} / \mathrm{ha}$; $\mathrm{PSB}=\mathrm{phosphorus}$ solubilizing bacteria; PSB0=control; PSB1= PSB $108 \mathrm{CFU} / 100 \mathrm{~g} /$ ha at sowing time only; PSB2=PSB $108 \mathrm{CFU} / 100 \mathrm{~g} / \mathrm{ha}$ at after over wintering only; PSB3=PSB 108 $\mathrm{CFU} / 100 \mathrm{~g} / \mathrm{ha}$ in dual fertilizing at sowing time and also after over wintering application
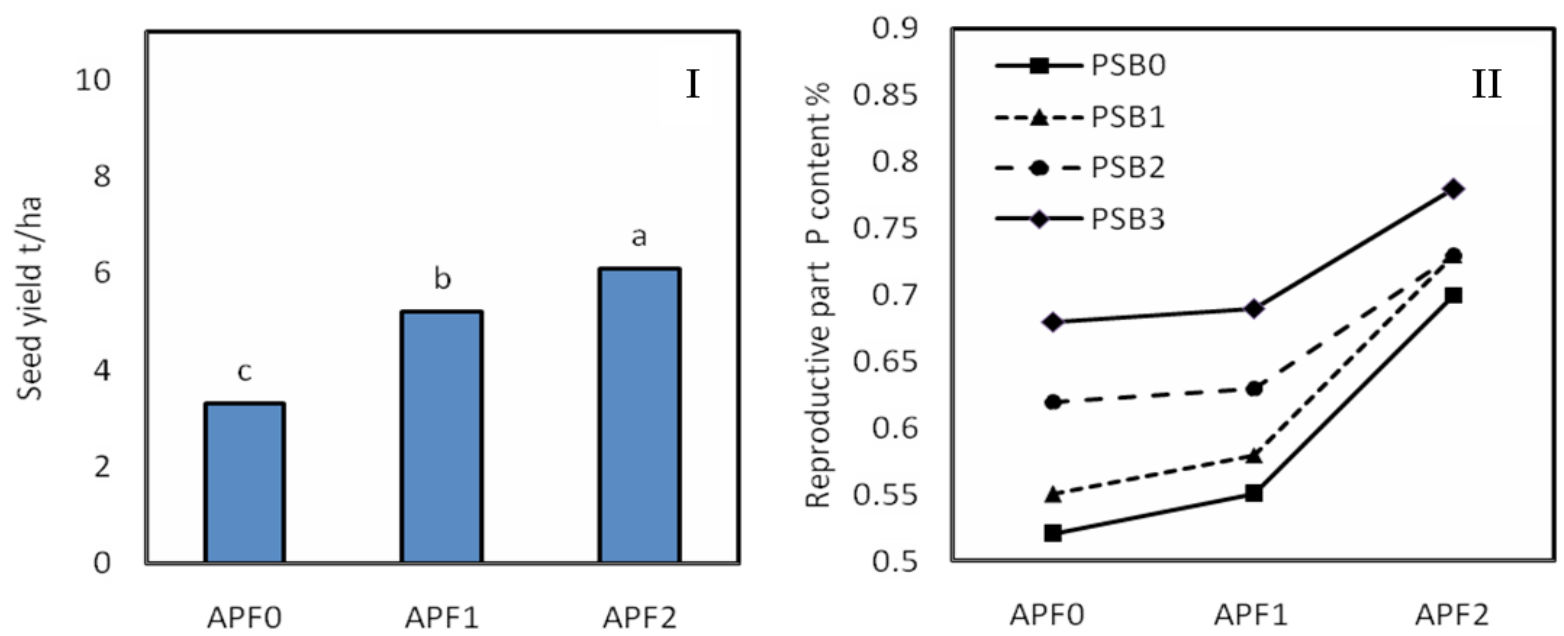

Fig. 1. Effect of APF application on Grain yield (I) and phosphorus content (\%) on reproductive plant parts (II). Control (AP0), $125 \mathrm{~kg} / \mathrm{ha}$ APF (AP1) and $250 \mathrm{~kg} / \mathrm{ha}$ (AP2) application. Control (PSB0), 100*10 ${ }^{8} \mathrm{CFU}$ PSB per $100 \mathrm{~g}$ bio-fertilizer at sowing time only (PSB1), $100^{*} 10^{8}$ CFU PSB per 100g bio-fertilizer as top dress fertilizer after over wintering only (PSB2) and $100^{*} 10^{8} \mathrm{CFU}$ PSB per $100 \mathrm{~g}$ bio-fertilizer at dual fertilizing in sowing time and also after over wintering application (PSB3) 

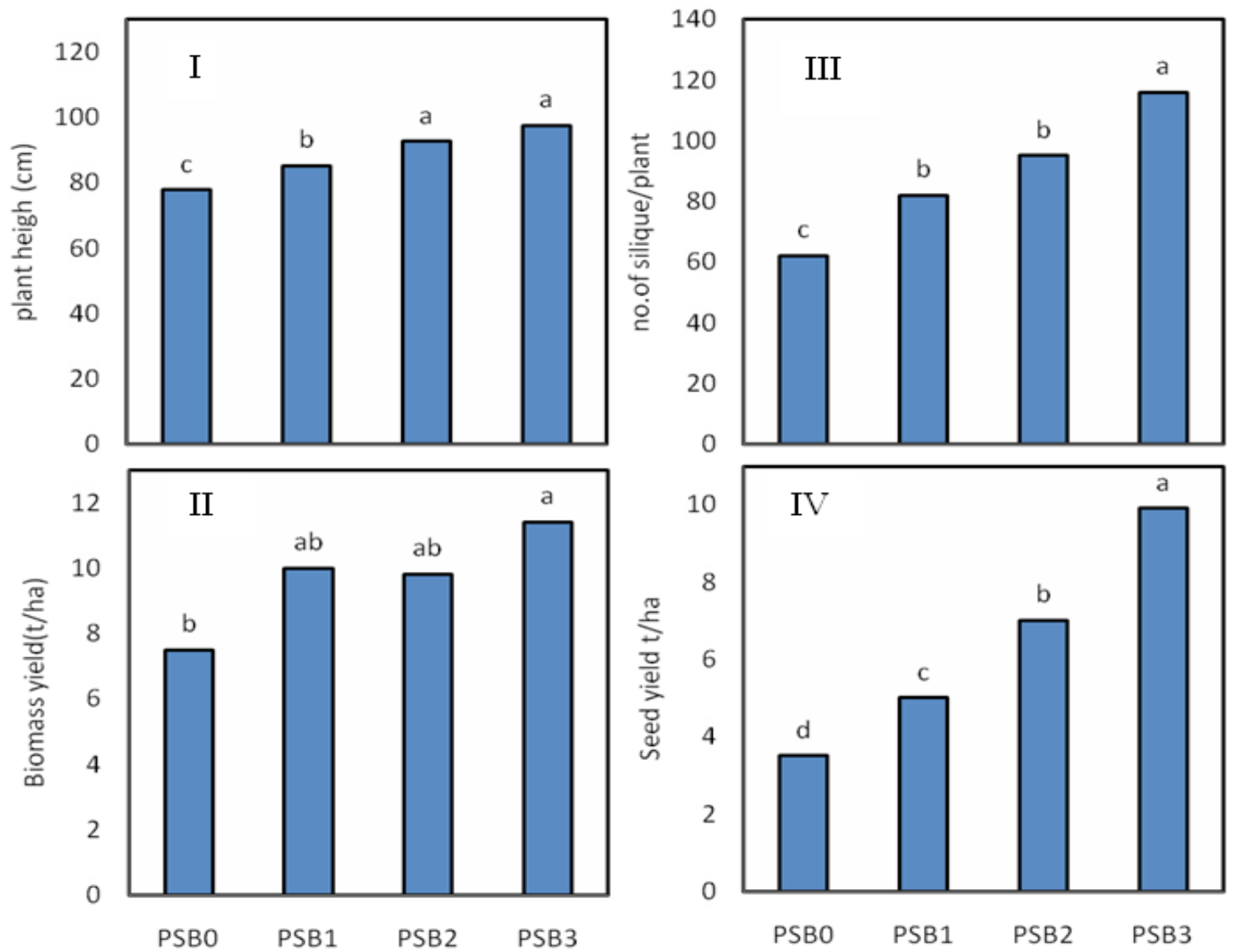

Fig. 2. Effects of PSB application on plant high (I) no. of silique per plant (II), biomass yield (III), and grain yield (IV). Control (PSB0), $100^{*} 10^{8}$ CFU PSB per $100 \mathrm{~g}$ bio-fertilizer at sowing time only (PSB1), $100^{*} 10^{8}$ CFU PSB per $100 \mathrm{~g}$ bio-fertilizer as top dress fertilizer after over wintering only (PSB2) and $100^{*} 10^{8}$ CFU PSB per $100 \mathrm{~g}$ bio-fertilizer at dual fertilizing in sowing time and also after over wintering (PSB3) application

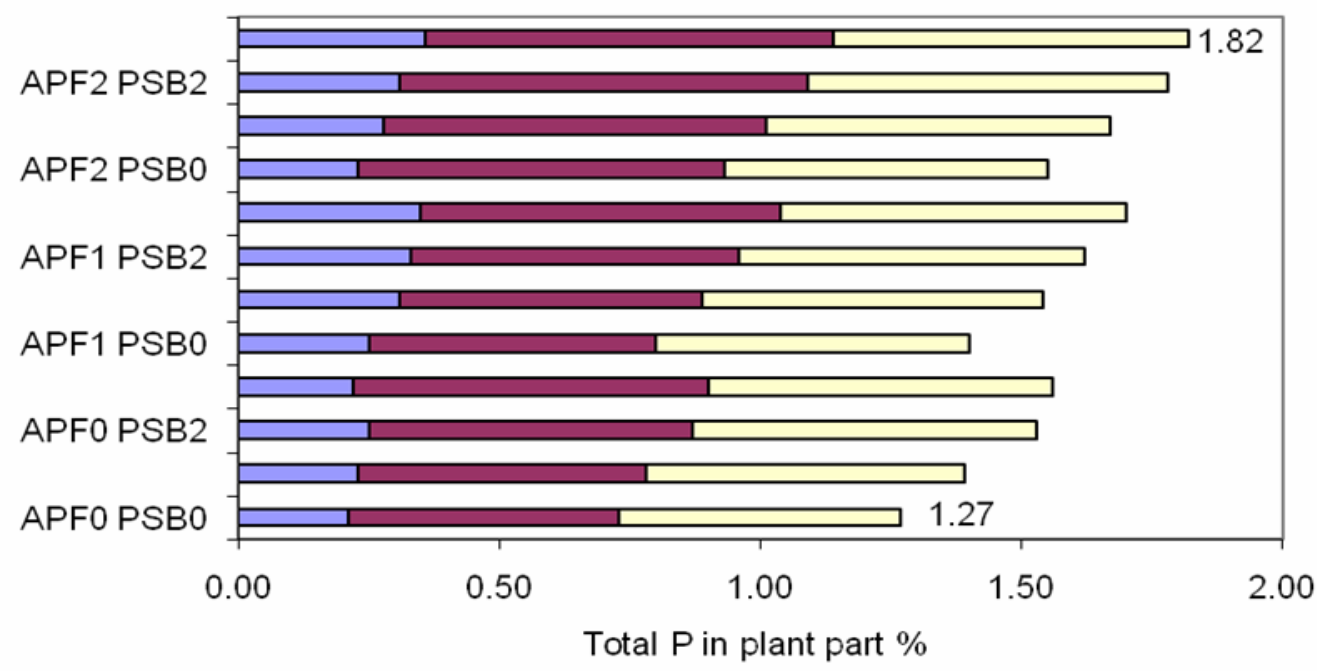

\section{$\square \mathrm{P}$ content in vegetative parts \\ 口P content inreproductive parts \\ $\square \mathrm{P}$ content in mature seeds}

Fig. 3. Phosphorus contents in the vegetative, reproductive plant parts and grains (\%). Control (AP0), $125 \mathrm{~kg} / \mathrm{ha} \mathrm{APF} \mathrm{(AP1)} \mathrm{and}$ $250 \mathrm{~kg} / \mathrm{ha}$ (AP2) application. Control (PSB0), $100^{*} 10^{8}$ CFU PSB per $100 \mathrm{~g}$ bio-fertilizer at sowing time only (PSB1), $100^{*} 10^{8}$ CFU PSB per $100 \mathrm{~g}$ bio-fertilizer as top dress fertilizer after over wintering only (PSB2) and $100^{*} 10^{8}$ CFU PSB per $100 \mathrm{~g}$ biofertilizer at dual fertilizing in sowing time and also after over wintering application (PSB3) 
214

was for control (3.02 t/ha). It seems that rapeseed crop develops well and produce grains when P availability in soil is fully supported.

Finally, these results show mainly phosphorus importance for plant nutrition in experimental soil condition. Thus, use of PSB fertilizer can be introduced as a proposal for increasing the grain production at the same condition as well as APF consumption.

\section{Effects of mixed use of PSB and APF}

The mixed use of PSB and APF application had not significant effect on plant height, biomass yield, number of silique per plant, seed oil percent and grain yield. Interaction effects of PSB and APF application were significant for phosphorus content in the plant tissues (Tab. 2).

Phosphorus content in vegetative and reproductive plant parts and also in mature grains was measured. The interaction effect of PSB fertilizer and APF showed that the phosphorus content in plant parts was significantly changed (Tab. 2). Minimum and maximum phosphorus content were $0.21 \%$ in vegetative plant parts for control and $0.36 \%$ in APF2PSB3. Different amount of phosphorus in reproductive plant parts indicated that the lowest phosphorus content was measured in control treatment. P content in reproductive rapeseed part was $0.52 \%$ in control and $0.78 \%$ in APF2PSB3 (Fig. 1, II).

Moreover, the mature grains could accumulate phosphorus very well. The highest phosphorus content in grains $(69 \%)$ was obtained in both combinations, APF2PSB2 and APF2PSB3. The rapeseed plant response to phosphorus accumulation at different growth and development stages showed a logical model. This is a descriptive factor for the PSB performance that can increase P content in plant. Many investigators had obtained similar results (Gupta et al., 1999; Ghoname and Shafeek, 2004).

\section{Conclusions}

Application of phosphor solubilizing bacteria alone as a basic phosphorus fertilizer could not add to phosphate compounds in plant parts. Increase of phosphorus content in plant parts by using chemical phosphorus fertilizers in association with phosphor solubilizing bacteria could cause major effects availability of soil phosphorus for rapeseed. The interaction effects of two different phosphorus fertilizer sources showed the phosphorus values in rapeseed was extensively affected by $\mathrm{P}$ availability in soil. Biomass yield was one of the most susceptible determinative characters to phosphorus solubilizing bacteria level. Use of PSB fertilizer can be a proposal for increasing the grain production at the same condition.

\section{References}

Alagawadi AR, Gaur AC (1992). Inoculation of Azospirillum brasilense and phosphate-solublizing bacteria on yield of sorghum (Sorghum bicolor L.) in dry land. Trop Agric (69):347-50.
Antoun H, Chabot R, Escas PC (1996). Growth promotion of maize and lettuce by phosphate solublizing Rhizobium leguminosarum biovar. phaseoli. Plant Soil 184:311-321.

Barraclough PB (1989). Root growth, macro-nutrient uptake dynamics and soil fertility requirements of a high-yielding winter oilseed rape crop. Plant Soil 119:59-70.

Chen YP, Rekha PD, Arun AB, Shen FT, Lai W-A, Young CC (2006). Phosphate solubilizing bacteria from subtropical soil and their tricalcium phosphate solubilizing abilities. App Soil Ecol 34:33-41.

Ghoname AA, Shafeek MR (2004). Growth and productivity of sweet pepper (Capsicum annum, L.) grown in plastic house as affected by organic, mineral and bio-N-fertilizer. Pak J Agron 4(4):369-372.

Goldstein AH (1986). Bacterial solubilization of mineral phosphates: historical perspective and future prospects Am J Alt Agric (1):51-57.

Gupta RP, Sharma VP, Singh DK, Srivastava KJ (1999). Effect of organic manures and inorganic fertilizers on growth, yield and quality of onion variety. Agrifound Dark Red. NHRDF News Letter 19(2/3):7-11.

Hinsinger P (2001). Bioavailability of soil inorganic P in the rhizosphere as affected by root-induced chemical changes: a review. Plant Soil 237(2):173-195.

Khalili A, Akbari N, Chiaichi MR (2008). Limited Irrigation and Phosphorus Fertilizer Effects on Yield and Yield Components of Grain Sorghum (Sorghum bicolor L.var. Kimia). Am-Euras J Agric Environ Sci 3(5):697-702.

Kloepper JW (1989). Free-living bacterial inoculate for enhancing crop productivity. Trends Biotechnol 7:39-44.

Nautiyal NJ (2000). Stress Induced phosphate solubilization in bacteria isolated from Alkaline soil FEMS. Microb Let 182:292-296.

Nikolay V, Franco I, Vassileva M, Azcon R (1996). Improved plant growth with rock phosphate solubilized by Aspergillus niger on sugar-beet waste Estacion. Biores Technol (55):237241.

Pant HK, Reddy KR (2003). Potential internal loading of phosphorus in wetlands constructed in agricultural. Land Water Res 37:965-972.

Ristimuki LM, Papadopoulos I, Sannwel C, Berhoyen NJ (2000). Slow release fertilizers on vegetables. Acta Hprt 511:125-131.

Shafeek MR, Faten S, Abd Al Ali El, Aisha H (2004). The productivity of broad bean plant as affected by chemical and/ or natural phosphorus with different bio-fertilizer. J Agric Sci Mansoura Univ 29(5):2727-2740.

Troug E, Mayer AH (1939). Improvement in the denies colorimetric method for phosphorus and arsenic. Indian Engineers chemical annual Ed 1:136-139.

Warade SD, Desale SB, Shinde KG (1996). Effects of organic inorganic and bio-fertilizers on yield of onion bulbs cv. 'B780'. J Maharashtra Agricult Univ (3):467-468. 